\title{
Crop diversification: A potential strategy to mitigate food insecurity by smallholders in sub-Saharan Africa
}

\author{
Ezekiel Mugendi Njeru ${ }^{3}$ b \\ Institute of Life Sciences, Sant' Anna School of Advanced Studies, and Kenyatta University
}

Submitted June 3, 2013 / Revised July 28, 2013 / Published online July 31, 2013

Citation: Mugendi Njeru, E. (2013). Crop diversification: A potential strategy to mitigate food insecurity by smallholders in sub-Saharan Africa. Journal of Agriculture, Food Systems, and Community Development, 3(4), 63-69. http://dx.doi.org/10.5304/jafscd.2013.034.006

Copyright (C 2013 by New Leaf Associates, Inc.

\begin{abstract}
As of 2010, about 239 million people in subSaharan Africa (SSA) were projected to be undernourished. With this figure expected to rise, concerted efforts to boost food production at the realm of global challenges such as climate instability and decline of nonrenewable resources are imperative. Food production in SSA presently faces the unprecedented challenge of producing sufficient and healthy food for the surging human population, while seeking to conserve the environment and reduce the use of nonrenewable resources and energy. Although over the past half century conventional agriculture has generally improved agricultural production in many parts of

a Institute of Life Sciences, Sant' Anna School of Advanced Studies, Piazza Martiri della Libertà n.33 - 56127, Pisa, Italy.

${ }^{\mathrm{b}}$ Department of Plant and Microbial Sciences, Kenyatta University, P.O. Box, 43844-00100, Nairobi, Kenya.

Email:njeruezek@gmail.com
\end{abstract}

the world, this has come at high economic and environmental costs since intensive agriculture relies heavily on off-farm inputs. Conventional agriculture is also dependent on the use of specific crop varieties or hybrids that have been bred specifically to exploit high-input conditions. Conversely, crop varieties used in high-input systems are not often adapted to low-input farming, a key element of many smallholder farming systems. The exploitation of crop genetic diversity as a strategy to increase food production by smallholders in SSA and elsewhere in the world has not been critically examined. This aspect may provide new insights to global food insecurity since crop diversification is a fundamental tool for improving yield stability and crop resilience under changing climatic conditions.

\section{Keywords}

crop diversification, smallholders, low-input agriculture, food security, sub-Saharan Africa 


\section{Introduction}

The development of resilient and affordable agricultural systems is especially vital in sub-Saharan Africa (SSA), where many communities depend largely on agricultural products (food, fodder, fuel) for their livelihoods (Altieri, 1999). The majority of farmers here are smallholders owning less than 5 acres ( 2 hectares) of land (which is likely to be further reduced due to current land fragmentation and unregulated urban center expansion) and practicing "low-resource" agriculture (Altieri, Funes-Monzote, \& Petersen, 2012). These farmers are more vulnerable to the overall effects of climate change since they have limited resources to invest in expensive coping strategies (Lin, 2011). Crop diversification is seen as one of the most ecologically feasible, cost-effective, and rational ways of reducing uncertainties in agriculture especially among small-scale farmers. This strategy is based on cultivating more than one variety of crops belonging to the same or different species in a given area. Crop diversification brings about higher spatial and temporal biodiversity on the farm and increases resilience, i.e., the ability of an agroecosystem to return to its original productive state after being perturbed (Holling, 1973).

Although crop diversification is not a novel concept to many rural communities in developing countries and emerging economies, only limited research on this subject has been conducted to date. However, there is renewed global interest in the area, mainly ascribed to the present rising concerns about loss of biodiversity, and human and environmental health. Therefore, more scientific expertise is desirable to identify which aspects of crop diversification could provide alternative and more viable tactics for crop production. Moreover, the potential of genetic diversification at the crop species level for improving production, resilience, and yield stability in low-input systems needs to be critically examined. We need to recognize crop genetic diversity as an essential tool for consistent production and an adaptation to changing weather and soil conditions. In this commentary, I will examine the role of crop diversification (within field-crop genetic diversity) in the context of some of the most challenging threats to sustainable food production by smallholders in SSA in this era of climate change, finite nonrenewable resources and energy, and economic uncertainties.

\section{Soil Fertility}

Low soil fertility and drought remain perennial constraints limiting food production in SSA (St.Clair \& Lynch, 2010). Poor farming practices, mainly those of continuous cropping with few external inputs, have gradually led to the depletion of soil fertility in smallholder systems. Recent estimates (Henao \& Baanante, 1999) show an annual nutrient loss per hectare in SSA of $22 \mathrm{~kg}$ nitrogen $(\mathrm{N}), 2.5 \mathrm{~kg}$ phosphorus $(\mathrm{P})$ and $15 \mathrm{~kg}$ potassium $(\mathrm{K})$. Thus, to increase sustainable food production and conserve soil fertility, alternative and more sustainable methods of production are fundamental. Central to soil health and crop productivity in natural ecosystems are beneficial soil microbiota in the rhizosphere. They provide essential agroecological services (Barrios, 2007; Myers, 1996), such as regulating biogeochemical cycling of both inorganic and organic nutrients in the soil, and in maintaining of soil quality (Jeffries, Gianinazzi, Perotto, Turnau, \& Barea, 2003).

Generally, crop species interact with beneficial soil biota in a very complex way, which is influenced by multiple genes and cues from both the host plant and the microorganism. Plant-microbial symbiosis is of key ecological relevance and intrinsic value to plant nutrition and stress tolerance. For example, arbuscular mycorrhizal fungi (AMF) belonging to the phylum Glomeromycota form symbiosis with more than $80 \%$ of terrestrial plants, increasing their nutritional uptake and resistance to biotic and abiotic stress (Smith \& Read, 2008). On the other hand, some agricultural crops species, especially brassicacea crops, do not form AMF symbiosis. Recent scientific findings have additionally shown that mycorrhizal symbiosis may vary depending on the crop cultivar, e.g. durum wheat (Singh, Hamel, DePauw, \& Knox, 2012), maize (An, Kobayashi, Enoki, Sonobe, Muraki, Karasawa, \& Ezawa, 2010), and tomato (Steinkellner, HageAhmed, García-Garrido, Illana, Ocampo, \& Vierheilig, 2012). More intriguing are the recent findings that modern genotypes could be less intensively colonized by AMF than ancestral ones (Lehmann, Barto, Powell, \& Rillig, 2012). On the 
other hand, legume-rhizobial symbiosis has been shown to vary with crop cultivar, for example, promiscuous soybean cultivars nodulate and fix nitrogen with a wider diversity of indigenous rhizobia than nonpromiscuous cultivars (Tefera, 2011). Thus, more comprehensive studies on crop diversification and microbial interactions are needed to enhance microbial symbiosis in smallholder systems.

To foster sustainable crop production, there is increasing use of cover crops in low-input and organic farming systems. Cover crops have been shown to effectively supply essential plant nutrients (Clark, 2007; Sainju, Singh, \& Whitehead, 2001), and to suppress plant diseases (Larkin, Griffin, \& Honeycutt, 2010; Ojaghian, Cui, Xie, Li, \& Zhang, 2012), weeds (Campiglia, Mancinelli, Radicetti, \& Caporali, 2010; Teasdale, 1996), and parasitic nematodes (Asmus, Inomoto, \& Cargnin, 2008; Wang, Sipes, \& Schmitt, 2002). Although the exploitation of cover crops has been studied extensively (Weil \& Kremen, 2007), many experiments have focused on single cover species rather than their functional diversity and management. However, owing to the unique nature of every plant cultivar and considering the niche complementarity effect and insurance hypothesis (Yachi \& Loreau, 1999), research should focus more on mixed cover crop species succeeded by diversified crops. Moreover, the growth of cover crop species as pure stands or mixed with natural weeds, which is typical of low-input and organic systems, could provide more information on management of cover crops since weeds may manipulate the functionality of the cover crop. This perspective is more likely bring new solutions for improving soil quality, plant-microbe interactions, and crop productivity in smallholder systems.

\section{Pest and Disease Control}

Smallholder farmers in SSA are currently faced with dramatic plant-protection issues resulting in food insecurity, reduced income attributable to lower production and export restrictions, and adverse effects of pesticide use on human health and on the surrounding environment (Ratnadass, Fernandes, Avelino, \& Habib, 2012). Motivated by the search for more economically feasible alternatives to suppress pests and diseases, presently, there are a myriad of ingenious traditional techniques used by rural farmers. Crop diversification by favoring species mixtures over monocultures is one of the most reasonable ways of controlling pests and disease and has generated a lot of interest in the recent years (Shoffner \& Tooker, 2013; Tooker \& Frank, 2012). Crop mixtures likely work by increasing natural enemies of insect pests, breaking the disease cycles and overwintering, suppressing weeds and volunteer crop plants, creating a dilution effect by reducing resource concentration, modifying the microenvironment within the crop canopy, or making pest and disease pathogen penetration more difficult.

In general, pests have different food or oviposition preferences, and thus will only attack certain plant species or cultivars at specific growth stages. Concurrently, the host plant must produce certain attractants or portray characteristics that make them attractive and vulnerable to certain pests. Thus, crop and habitat diversification (Hokkanen, 1991; Ratnadass et al., 2012) targeting to break this synergy could form an effective control mechanism for many pests that threaten crop production in SSA. For example, interest in trap crops, a traditional tool of pest management (Shelton \& Badenes-Perez, 2006), and the pushpull strategy (Hassanali, Herren, Khan, Pickett, \& Woodcock, 2008) has considerably increased over the past years. The push-pull strategy, also referred to as stimulo-deterrent diversionary strategy, entails the control of pests by repelling them from the main crop (push) using stimuli that masks a host or is repellent or a deterrent while simultaneously attracting (pull) the pest, using highly attractive stimuli, to other areas such as traps or trap crops where they are concentrated and eventually eliminated (Cook, Khan, \& Pickett, 2006; Miller \& Cowles, 1990). Recent studies have reported successful control of lepidopteran stem borers on maize crop in Kenya, by employing crop mixtures in push-pull strategies (Hassanali et al., 2008), a technique so far adopted by more than 30,000 farmers across East Africa (Khan, Midega, Bruce, Hooper, \& Pickett, 2010).

Elsewhere, although crop genetic diversity has been reported to produce less predictable results in 
plant-disease suppression than in the control of pests (Lin, 2011), using cultivar mixtures has been shown to control some plant diseases (Juroszek \& von Tiedemann, 2011; Krupinsky, Bailey, McMullen, Gossen, \& Turkington, 2002), including potato late blight, maize northern and southern leaf blight diseases in China (Xiahong, Shusheng, Haining, Yong, Yan, \& Dong, 2010), blast disease in rice (Zhu, Chen, Fan, Wang, Li, \& Chen, 2000), and Fusarium wilt in cotton (Yang, Ge, Ouyang, \& Parajulee, 2012), among others. Thus, present research should focus on crop diversification as an entity to promote plant health while integrating other feasible cost-efficient and environmentally friendly methods, especially under integrated pest management.

\section{Yield Stability, Nutrition Diversity, and Health}

Yield stability is one of the most fundamental components targeted by most smallholder farmers. Majority of smallholders depend on seasonal yields for food and economic returns. Thus, the implications of yield fluctuation can be very profound since it means less food is available for the family and a lower income for other basic needs. Investment in crop diversification will help cushion smallholders from food insecurity due to the likely general increase in yields, as reported by several previous studies (such as Cowger \& Weisz, 2008), and bring yield stability and insurance effect (Yachi \& Loreau, 1999), since if one crop fails they can still depend on the other crop. In a review of 100 studies of intraspecific crop mixtures (mostly grains and legumes), (Smithson and Lenné, 1996) concluded that yields were often slightly higher compared to pure stands of component cultivars. Recently, increasing crop diversity by intercropping of tobacco, maize, sugarcane, potato, wheat, and broad bean was reported to increase yields for the same season between $33.2 \%$ and $84.7 \%$ for some combinations (Li, He, Zhu, Zhou, Wang, \& Li, 2009). Similarly, a recent meta-analysis study reported increased grain yields of cereals in field trials of cereal variety mixtures (Kiær, Skovgaard, \& Østergård, 2009). Thus, since in the near future shifts in local climatic conditions and the frequency of extreme weather events are expected to be worse, with potentially devastating effects for agricultural yields, strategies need to be developed to make our food and farming systems more resilient to the effects of climate change.

The combination of various crops in agroecosystems not only permits more efficient utilization of agroecological processes, but also provides diversity for human diet or improves household income, allowing purchase of alternative food. Thus diversification of production and consumption habits to include a broader range of plant species, in particular those currently identified as underutilized, can contribute significantly to improved health and nutrition, livelihoods, household food security, and ecological sustainability. Future research in African cropping systems should explore both modern and traditional crop varieties to enhance nutritional diversification.

\section{Breeding for Low-input Systems}

Until today, just one and half years before year 2015, the yardstick for achieving millennium development goals, ${ }^{1}$ there are millions of smallholders in SSA practicing low-input agriculture and contributing to the global food basket. This clearly indicates some remarkable resiliency of low-input agroecosystems despite the continuously changing environment and shrinking economy. Therefore, in the successful development of long-term adoption of ecologically and sustainable food systems, the involvement of local farmers and integration of local knowledge will be crucial. Conversely, there is increasing domination by a few seed companies in providing seeds of major crops in SSA and continuing pressure on farmers to abandon their traditional crop varieties. Such an approach has resulted in production of ephemeral hybrids poorly adapted to cope with local conditions and the loss of traditional landraces and varieties, such as the disappearance of githigu, a very popular traditional maize variety in central Kenya (Wambugu \& Muthamia, 2009).

Evolutionary breeding additionally forms an important area of research geared towards increasing crop diversification. Instead of mixing pure

\footnotetext{
${ }^{1}$ See the United Nations' Millennium Development Goals at http://www.un.org/millenniumgoals/
} 
lines or finished varieties, multiple crosses (often called composite cross populations) are made among varieties possessing characteristics of interest (Wolfe, Baresel, Desclaux, Goldringer, Hoad, \& Kovacs, 2008). The progeny of the composite crosses is then left to adapt to local conditions. This approach is especially amenable to the participation of farmers in the process of selection and breeding, and would allow for onfarm development and maintenance of genetic resources. Under participatory breeding, breeders must identify farmers' needs, search for suitable materials in collaboration with farmers, and test such materials on farmers' fields. Such an approach will likely increase diversification in smallholder systems and final crop production.

\section{Conclusions}

Future research should focus on more ingenious ways of managing low-input crop productivity in smallholder systems, a key characteristic of crop production in SSA. Novel low-input cropping systems in SSA will require an understanding of crop diversity (intra- and interspecific), and management diversity. This calls for more funding since large-scale agro- ecological experiments on farmers' fields are often expensive and challenging compared to greenhouse experiments. New approaches and technologies that apply blended modern agricultural science and indigenous knowledge, and integrate local farmers as main stakeholders, are likely to offer more practical solutions to food insecurity in SSA.

\section{References}

Altieri, M. A. (1999). The ecological role of biodiversity in agroecosystems. Agriculture, Ecosystems \& Environment, 74(1-3), 19-31. http://dx.doi.org/10.1016/S0167-8809(99)00028-6

Altieri, M. A., Funes-Monzote, F., \& Petersen, P. (2012). Agroecologically efficient agricultural systems for smallholder farmers: Contributions to food sovereignty. Agronomy for Sustainable Development, 32(1), 1-13. http://dx.doi.org/10.1007/s13593011-0065-6

An, G.-H., Kobayashi, S., Enoki, H., Sonobe, K., Muraki, M., Karasawa, T., \& Ezawa, T. (2010). How does arbuscular mycorrhizal colonization vary with host plant genotype? An example based on maize (Zea mays) germplasms. Plant and Soil, 327(12), 441-453. http://dx.doi.org/10.1007/s11104009-0073-3

Asmus, G. L., Inomoto, M. M., \& Cargnin, R. A. (2008). Cover crops for reniform nematode suppression in cotton: Greenhouse and field evaluations. Tropical Plant Pathology, 33(2), 85-89. http://dx.doi.org/ 10.1590/S1982-56762008000200001

Barrios, E. (2007). Soil biota, ecosystem services and land productivity. Ecological Economics, 64(2), 269-285. http://dx.doi.org/10.1016/j.ecolecon.2007.03.004

Campiglia, E., Mancinelli, R., Radicetti, E., \& Caporali, F. (2010). Effect of cover crops and mulches on weed control and nitrogen fertilization in tomato (Lycopersicon esculentum Mill.). Crop Protection, 29(4), 354-363. http://dx.doi.org/10.1016/j.cropro.2009.12.001

Clark, A. (Ed.). (2007). Managing cover crops profitably(3 Ed.). Beltsville, Maryland: U.S. Department of Agriculture.

Cook, S. M., Khan, Z. R., \& Pickett, J. A. (2006). The use of push-pull strategies in integrated pest management. Annual Review of Entomology, 52, 375 400. http://dx.doi.org/10.1146/annurev.ento. $\underline{52.110405 .091407}$

Cowger, C., \& Weisz, R. (2008). Winter wheat blends (mixtures) produce a yield advantage in North Carolina. Agronomy Journal, 100(1), 169-177. http://dx.doi.org/10.2134/agrojnl2007.0128

Hassanali, A., Herren, H., Khan, Z. R., Pickett, J. A., \& Woodcock, C. M. (2008). Integrated pest management: The push-pull approach for controlling insect pests and weeds of cereals, and its potential for other agricultural systems including animal husbandry. Philosophical Transactions of the Royal Society B: Biological Sciences, 363(1491), 611-621. http://dx.doi.org/10.1098/rstb.2007.2173

Henao, J., \& Baanante, C. (1999). Estimating rates of nutrient depletion in soils of agricultural lands of Africa. Muscle Shoals, Alabama: International Fertilizer Development Center.

Hokkanen, H. M. T. (1991). Trap cropping in pest management. Annual Review of Entomology, 36, 119138. http://dx.doi.org/10.1146/annurev.en. $\underline{36.010191 .001003}$ 
Holling, C. S. (1973). Resilience and stability of ecological systems. Annual Review of Ecology and Systematics, 4, 1-23. http://dx.doi.org/10.1146/ annurev.es.04.110173.000245

Jeffries, P., Gianinazzi, S., Perotto, S., Turnau, K., \& Barea, J.-M. (2003). The contribution of arbuscular mycorrhizal fungi in sustainable maintenance of plant health and soil fertility. Biology and Fertility of Soils, 37(1), 1-16. http://dx.doi.org/10.1007/s00374-002-0546-5

Juroszek, P., \& von Tiedemann, A. (2011). Potential strategies and future requirements for plant disease management under a changing climate. Plant Pathology, 60(1), 100-112. http://dx.doi.org/ 10.1111/j.1365-3059.2010.02410.x

Khan, Z. R., Midega, C. A. O., Bruce, T. J. A., Hooper, A. M., \& Pickett, J. A. (2010). Exploiting phytochemicals for developing a 'push-pull' crop protection strategy for cereal farmers in Africa. Journal of Experimental Botany, 61(15), 4185-4196. http://dx.doi.org/10.1093/jxb/erq229

Kiær, L. P., Skovgaard, I. M., \& Østergård, H. (2009). Grain yield increase in cereal variety mixtures: A meta-analysis of field trials. Field Crops Research, 114(3), 361-373. http://dx.doi.org/10.1016/i.fcr.2009.09.006

Krupinsky, J. M., Bailey, K. L., McMullen, M. P., Gossen, B. D., \& Turkington, T. K. (2002). Managing plant disease risk in diversified cropping systems. Agronomy Journal, 94(4), 198-209. http://dx.doi.org/10.2134/agronj2002.955a

Larkin, R. P., Griffin, T. S., \& Honeycutt, C. W. (2010). Rotation and cover crop effects on soilborne potato diseases, tuber yield, and soil microbial communities. Plant Disease, 94(12), 1491-1502. http://dx.doi.org/10.1094/pdis-03-10-0172

Lehmann, A., Barto, E. K., Powell, J. R., \& Rillig, M. C. (2012). Mycorrhizal responsiveness trends in annual crop plants and their wild relatives — a meta-analysis on studies from 1981 to 2010. Plant and Soil, 355(12), 231-250. http://dx.doi.org/10.1007/s11104011-1095-1

Li, C., He, X., Zhu, S., Zhou, H., Wang, Y., Li, Y.,...Zhu, Y. (2009). Crop diversity for yield increase. PLoS ONE, 4(11), e8049. http://dx.doi.org/10.1371/journal.pone.0008049
Lin, B. B. (2011). Resilience in agriculture through crop diversification: Adaptive management for environmental change. BioScience, 61, 183-193. http://dx.doi.org/10.1525/bio.2011.61.3.4

Miller, J. R., \& Cowles, R. S. (1990). Stimulo-deterrent diversion: A concept and its possible application to onion maggot control. Journal of Chemical Ecology, 16(11), 3197-3212. http://dx.doi.org/10.1007/bf00979619

Myers, N. (1996). Environmental services of biodiversity. Proceedings of the National Academy of Sciences, 93(7), 2764-2769. http://dx.doi.org/10.1073/pnas.93.7.2764

Ojaghian, M. R., Cui, Z.-Q., Xie, G.-L., Li, B., \& Zhang, J. (2012). Brassica green manure rotation crops reduce potato stem rot caused by Sclerotinia sclerotium. Australasian Plant Pathology, 41(4), 347-349. http://dx.doi.org/10.1007/s13313-012-0142-6

Ratnadass, A., Fernandes, P., Avelino, J., \& Habib, R. (2012). Plant species diversity for sustainable management of crop pests and diseases in agroecosystems: A review. Agronomy for Sustainable Development, 32(1), 273-303. http://dx.doi.org/10.1007/s13593-011-0022-4

Sainju, U. M., Singh, B. P., \& Whitehead, W. F. (2001). Comparison of the effects of cover crops and nitrogen fertilization on tomato yield, root growth, and soil properties. Scientia Horticulturae, $91(3-4)$, 201-214. http://dx.doi.org/10.1016/S03044238(01)00264-3

St. Clair, S. B., \& Lynch, J. P. (2010). The opening of Pandora's Box: Climate change impacts on soil fertility and crop nutrition in developing countries. Plant and Soil, 335(1-2), 101-115. http://dx.doi.org/10.1007/s11104-010-0328-z

Shelton, A. M., \& Badenes-Perez, F. R. (2006). Concepts and applications of trap cropping in pest management. Annual Review of Entomology, 51, 285308. http://dx.doi.org/10.1146/annurev.ento. $\underline{51.110104 .150959}$

Shoffner, A. V., \& Tooker, J. F. (2013). The potential of genotypically diverse cultivar mixtures to moderate aphid populations in wheat (Triticum aestivum L.). Arthropod-Plant Interactions, 7(1), 33-43. http://dx.doi.org/10.1007/s11829-012-9226-Z 
Singh, A. K., Hamel, C., DePauw, R. M., \& Knox, R. E. (2012). Genetic variability in arbuscular mycorrhizal fungi compatibility supports the selection of durum wheat genotypes for enhancing soil ecological services and cropping systems in Canada. Canadian Journal of Microbiology, 58(3), 293-302. http://dx.doi.org/10.1139/w11-140

Smith, S. E., \& Read, D. J. (2008). Mycorrbizal symbiosis(Third Ed.). London: Academic Press.

Smithson, J. B., \& Lenné, J. M. (1996). Varietal mixtures: A viable strategy for sustainable productivity in subsistence agriculture. Annals of Applied Biology, 128(1), 127-158. http://dx.doi.org/10.1111/j.17447348.1996.tb07096.x

Steinkellner, S., Hage-Ahmed, K., García-Garrido, J. M., Illana, A., Ocampo, J. A., \& Vierheilig, H. (2012). A comparison of wild-type, old and modern tomato cultivars in the interaction with the arbuscular mycorrhizal fungus Glomus mosseae and the tomato pathogen Fusarium oxysporum f. sp. lycopersici. Mycorrhiza, 22(3), 189-194. http://dx.doi.org/ 10.1007/s00572-011-0393-z

Teasdale, J. R. (1996). Contribution of cover crops to weed management in sustainable agricultural systems. Journal of Production Agriculture, 9(4), 475479. http://dx.doi.org/10.2134/jpa1996.0475

Tefera, H. (2011). Breeding for promiscuous soybeans at IITA.In A. Sudaric (Ed.), Soybean - Molecular Aspects of Breeding (chap. 7). http://dx.doi.org/10.5772/14533

Tooker, J. F., \& Frank, S. D. (2012). Genotypically diverse cultivar mixtures for insect pest management and increased crop yields. Journal of Applied Ecology, 49(5), 974-985. http://dx.doi.org/ 10.1111/j.1365-2664.2012.02173.x

Wambugu, P. W., \& Muthamia, Z. K. (Eds.) (2009). The state of plant genetic resources for food and agriculture in
Kenya. Nairobi: Kenya Agricultural Research Institute, National Genebank of Kenya.

Wang, K.-H., Sipes, B. S., \& Schmitt, D. P. (2002). Crotalaria as a cover crop for nematode management: A review. Nematropica, 32(1), 35-58. Available at http://journals.fcla.edu/nematropica/

Weil, R., \& Kremen, A. (2007). Thinking across and beyond disciplines to make cover crops pay. Journal of the Science of Food and Agriculture, 87(4), 551-557. http://dx.doi.org/10.1002/jsfa.2742

Wolfe, M. S., Baresel, J. P., Desclaux, D., Goldringer, I., Hoad, S., Kovacs, G.,...Lammerts van Bueren, E. T. (2008). Developments in breeding cereals for organic agriculture. Euphytica, 163(3), 323-346. http://dx.doi.org/10.1007/s10681-008-9690-9

Xiahong, H., Shusheng, Z., Haining, W., Yong, X., Yan, S., Dong, G.,... Youyong, Z. (2010). Crop diversity for ecological disease control in potato and maize. Journal of Resources and Ecology, 1(1), 45-50. http://dx.doi.org/10.3969/i.issn.1674$\underline{764 x .2010 .01 .006}$

Yachi, S., \& Loreau, M. (1999). Biodiversity and ecosystem productivity in a fluctuating environment: The insurance hypothesis. Proceedings of the National Academy of Sciences of the United States of America, 96(4), 1463-1468. http://dx.doi.org/10.1073/pnas.96.4.1463

Yang, B., Ge, F., Ouyang, F., \& Parajulee, M. (2012). Intra-species mixture alters pest and disease severity in cotton. Environmental Entomology, 41(4), 1029_ 1036. http://dx.doi.org/10.1603/en11182

Zhu, Y., Chen, H., Fan, J., Wang, Y., Li, Y., Chen, J.,...Mundt, C. C. (2000, August 17). Genetic diversity and disease control in rice. Nature, 406, 718-722. http://dx.doi.org/10.1038/35021046 